\title{
The Legal Basis of School Administration
}

\section{Murat ÖZDEMIR*}

\begin{abstract}
The school administrators are one of the main actors in term of achieving schools' purposes. The goal of this study is to discuss the legal basis of school administration. On this account, Constitution, laws, regulations and circulars related to school administration were revised comprehensively and the current position of school administration was described according to positive laws. Furthermore, the literature about school administration was examined and the situation that is supposed to be according to ideal laws was analyzed. At the end of the study it was seen that the current laws which regulates the promotion of administrators was in contradiction with merit and career principles and it was suggested that this situation should be re-regulated. In addition, the duties of administrators were analyzed and found that the legal position that regulates these duties were not contemporary and suggested that they should be rearranged.
\end{abstract}

Key Words: School administration, principal, educational regulations.

\section{SUMMARY}

The purpose of this study was to describe and analyze the legal basis of school administration. This study was limited to legal foundations of school administration who work at elementary and high schools belonging to Ministry of National Education. But the administrators at higher education institutions were not involved in this study.

* Ph.D. Candidate, Ankara University, Institute of Educational Sciences, Department of Educational Administration and Politics.mrtozdem@gmail.com 
The current study is a review. The data which were used to describe and analyze the legal position of school administrators were gathered from regulations and literature. At first the importance of school administrators were discussed in order to explain their roles at schools' success. Then the relationship between the public laws and education was examined. In this section the social, political and economic parameters were analyzed in order to find out the legal foundations of school education in Turkey. The discussions about the reason why and how the education became one of the important public services showed that the education system in Turkey was organized according to hierarchy principle which was developed by Weber. For this reason, the Constitution, laws, regulations and circulars which regulate the education system in general and the schools in particular were prepared according to hierarchy principle. This situation has also affected the positions and the roles of school administrators. That is, the main role of school administrators is just to apply the commands which are ordered by their superiors. On the contrary, decentralization of education became the most popular trend in many countries. Decentralization of education strengthened the empowerment of school administrators in many developed countries including USA, Britain and Canada.

The discussions about how school administrators are prepared and selected also showed that preparing and selection processes of school administrators have not been effective in Turkey for many years. Therefore it was understood that the regulations about preparing and selecting of school administrators must be rearranged with the contemporary developments as in many developed countries.

With the current study, primary duties of school administrators were classified into four categories which are personnel services, education and instruction services, student services and business enterprise services. When these services were analyzed it was seen that the regulations about these services are out of date compared to trends which is seen in many developed countries. Therefore, it was suggested with this study that the legal regulations about the main duties of school administrators should be reregulated according to the basic principles of contemporary educational developments. 


\title{
Okul Yöneticiliğinin Hukuksal Temelleri
}

\author{
Murat ÖZDEMIR*
}

ÖZ. Okulun amaçlarına ulaşmasında rol oynayan aktörlerin başında okul yöneticileri gelmektedir. Bu çalışmanın temel amacı, okul yöneticiliğinin hukuksal temellerini irdelemektir. $\mathrm{Bu}$ amaç doğrultusunda, Türkiye'de okul yöneticiliği ile ilgili olmak üzere başta Anayasa, yasa, tüzük, yönetmelik ve yönergeler kapsamlı bir şekilde taranmış ve böylece okul yöneticiliğinin mevcut durumu pozitif hukuk çerçevesinde betimlenmiştir. Ayrıca, okul yöneticiliği ile ilgili alanyazın incelenmiş ve ideal hukuk normları çerçevesinde olması gereken durumun bir analizi yapılmıştır. Çalışmanın sonunda, okul yöneticilerinin göreve atanma biçimini düzenleyen mevcut hukuksal durumun liyakat ve kariyer ilkesi ile çeliştiği görülmüş ve bu durumun yeniden düzenlenmesi gerektiği önerilmiştir. Çalışmada ayrıca yöneticilerin görev alanları analiz edilmiş ve bu alanları düzenleyen yasal durumun çağdaş gelişmelerin gerisinde kaldığı, dolayısıyla yeniden düzenlenmesi gerektiği sonucuna ulaşılmıştır.

Anahtar Sözcükler. Okul yöneticiliği, okul müdürü, eğitim mevzuatı

\section{GİRIŞ̧}

Bireyin eğitilmesi sürecinde aile, din ve kitle iletişimi gibi kurumlar önemli bir işleve sahip olsa da, planlı bir etkinlik olarak eğitim girişimi okulda gerçekleşmektedir (Bloom, 1998: 8). Bu anlamda okulu, eğitim sisteminde eğitim hizmetinin üretildiği bir örgüt olarak tanımlanmak da mümkündür (Başaran, 2000: 12). Okul, aynı zamanda öğrenci, öğretmen ve yönetici gibi farklı rollere sahip aktörlerin karşl1ıklı etkileşim içerisinde oldukları sosyal bir sistemdir. Bu sistemin unsurlarından biri olan yönetici, okulun eğitsel amacı gerçekleştirmesine dönük etkinlikleri planlayan, örgütleyen ve son aşamada denetimini gerçekleştiren bir alan uzmanıdır. Bu

* Doktora Öğrencisi, Ankara Üniversitesi, Eğitim Bilimleri Enstitüsü, Eğitim Yönetimi ve Politikası Anabilim Dalı,mrtozdem@gmail.com 
yönüyle yönetici, eğitim politikalarının uygulanması, okulda öğretimin gerçekleştirilmesi ve geliştirilmesi gibi etkinliklerde önemli bir rol oynamaktadır (Balc1, 1988).

Yöneticinin, okulun amaçlarını gerçekleştirme sürecindeki çabası, eğitimsel gerçekliğin etkileşim içerisinde olduğu politik, ekonomik ve kültürel parametreler tarafından biçimlendirilmektedir. Söz konusu parametrelerin yöneticinin edimleri üzerindeki etkisi, yürürlükteki hukuk düzeni ve bu düzene özgü yaptırım mekanizmaları aracılığı ile gerçekleşmektedir. Şu halde yöneticinin eğitim ve okul sistemi içerisindeki konumu ve hareket alanının çözümlenmesi süreci, hukuksal düzeninin etkileştim içerisinde olduğu politik, ekonomik ve kültürel parametrelerin çözümünü gerekli kılmaktadır.

$\mathrm{Bu}$ çalışmanın temel amacı, Milli Eğitim Bakanlığına (MEB) bağlı örgün eğitim kurumlarında çalışan okul yöneticilerinin okul sistemi içerisindeki yerini, ideal ve pozitif hukukun özgün temaları çerçevesinde çözümlemektir. Bu çözümlemede öncelikli olarak, mevcut okul sisteminin üzerinde yükseldiği Türk kamu yönetimi rejimi ve bu rejimin işleyişini biçimlendiren kamu hukuku düzeni betimlenmiş; ardından, eğitim uygulamalarına yön veren yasal temeller irdelenmiştir. Bu amaçla, başta 1982 Anayasası olmak üzere eğitim uygulamalarının dayandığı yasa, yönetmelik ve yönergeler kapsamlı bir biçimde incelenmiştir. Çalışma temel olarak, yöneticilerin göreve atanma usulü ile yetki, görev ve sorumluluk alanları ile sınırlı tutulmuş olup, söz konusu alanların temel özellikleri ayrıntılı bir biçimde betimlenmiştir. Diğer yandan okul yöneticilerini merkeze alan alanyazın taranmış; böylece okul yöneticiliğini konu edinen mevcut yasal durum ile olması gereken durumun karşılaştırılmasına dayalı bir çözümleme yöntemi benimsenmiştir.

\section{Eğitimin Yasal Dayanakları ve Okul Müdürü}

Okul toplumunun en önemli halkalarından biri okul müdürüdür. Müdür, okulun insan ve fizik kaynaklarını, eğitsel amacın en etkili biçimde gerçekleşmesi yönünde eşgüdümleyen ve işekoşan bir işgörendir. Müdürün bu süreçteki yetki, görev ve sorumlulukları büyük oranda eğitimi kuşatan hukuk rejimi tarafından belirlenmektedir. Eğitim etkinliklerine yön veren hukuk rejimi ise siyasal, sosyal ve ekonomik parametreler ile yoğun bir ilişki içerisindedir. Aşağıda, eğitim girişiminin temel aktörlerinden biri olan müdürün, hukuk rejimi içerisindeki konumlanışı ve rolü, eğitim ve hukuk ilişkisi zemininde betimlenmiştir. 


\section{Kamu Hukukunda Eğitim}

Türkiye'de eğitim, tarihsel gelişimi içerisinde kimi sosyal, siyasal ve iktisadi nedenlerden dolayı temel bir kamu hizmetine dönüşmüștür (Özdemir, 2008a). Eğitimin kamusallaşması ile birlikte eğitim ve okul yönetimi giderek kamu yönetiminin bir alt sistemi haline gelmiştir (Bursalığlu, 2002: 5; Taymaz, 2003: 20). Türk kamu yönetimi rejiminin merkeziyetçi yapısı nedeniyle (Eryılmaz, 2002: 79; Güler, 2000) eğitim yönetimi de merkeziyetçi bir anlayışla örgütlenmiştir (Özdemir, 2008b).

Eğitim yönetiminde gözlenen kamusallaşma ve merkezileşme eğilimi, sistemi kuran ve işleten hukuk rejiminin de baskın bir biçimde kamu hukuku normlarına göre yapılandırılmasına yol açmıştır. Kamu hukuku, kamu yönetimi ile bireyler ve kamu kurumları ile özel kurumlar arasındaki ilişkiler üzerine odaklanan hukukun bir dalıdır (Bozkurt ve Ergun, 1998: 130). Türkiye'de kamu yönetimine kural olarak kamu hukukunun bir dalı olan yönetim hukuku uygulanmaktadır (Gözübüyük, 2002: 14). Yönetim hukukunun kaynakları ise başta anayasa olmak üzere, kanun, tüzük, yönetmelik ve yargı içtihatlarıdır (Günday, 2002: 32).

Türkiye'de eğitim hizmetlerini düzenleyen ve eğitime konu olan diğer tüm düzenlemelerin hukuksal dayanağını 1982 yılında yürürlüğe girmiş olan Türkiye Cumhuriyeti Anayasası oluşturmaktadır. Anayasanın 42. maddesi eğitimin, devletin gözetim ve denetimi altında yapılacağını ve kapsamının kanunla belirleneceğini öngörmüştür.

Anayasanın bu amir hükmüne dayalı olarak, Türkiye'de eğitimin gözetim ve denetim işlerini Milli Eğitim Bakanlığı (MEB) yürütmektedir. MEB'in örgütlenme biçimi ve görevleri 1992 y1lında yürürlüğe girmiș bulunan 3797 sayılı Milli Eğitim Bakanlığı Teşkilat ve Görevleri Hakkında Kanun ile belirlenmiştir. Kanuna göre bakanlık merkez, taşra ve yurt dış1 örgütlerinden oluşmaktadır (m. 3). MEB' in merkez örgütünün başında bakan bulunmaktadır. Bakanın birinci derecede yardımcısı bakanlık müsteşarı olup, müsteşarın yedi yardımcısı bulunmaktadır.

Yine 3797 sayılı Kanun'a göre, bakanlık merkez örgütü on altı ana hizmet birimine ayrılmış ve bu birimler genel müdürlük biçiminde örgütlenmiştir. Ana hizmet birimlerine destek hizmeti vermek üzere ise bakanlık merkez örgütü bünyesinde on dört yardımcı birim kurulmuştur. Bakanlık merkez örgütünün bir diğer önemli bileşeni ise danışma ve denetim birimleridir. Bu birimlerin temel görevi, bakanlığa bağlı tüm birimleri teftiş etmek, incelemelerde bulunmak ve soruşturma yapmaktır. Bakanlığın taşra teşkilatını ise il ve ilçelerde kurulmuş olan milli eğitim müdürlükleri oluşturmaktadır (m. 53). 
Görüldüğü üzere 3797 sayılı kanun, MEB'in örgütsel yapısını piramit devlet anlayışına göre desenlemiştir. Bu yapı Weber'in geliştirilmiş olduğu bürokrasi kuramı ve bu kuramın temel ilkeleri referans alınarak (Weber, 1996: 81) inşa edilmiştir. Bu anlayışın bir sonucu olarak MEB, merkeziyetçi yönü ağır basan bir örgüte dönüşmüştür.

\section{Eğitim Yöneticiliğine Atanma}

MEB'in merkeziyetçi örgüt yapısını biçimlendiren ve düzenleyen hukuksal yapı aynı zamanda, sistemin çeşitli kademelerinde çalışan yöneticilerin sistemdeki konumlanışını, hareket alanını ve davranışlarını da belirlemektedir. Şu halde eğitim yöneticisi, üyesi bulunduğu örgütün amaç, yap1 ve süreçleriyle ilgili işleyişi düzenleyen hukuki normların bir uygulayıcısı durumundadır. Örneğin, MEB teşkilat kanuna göre (3797) bakanlığa bağlı yöneticiler görevlerini "mevzuat, plân, program ve emirlere uygun olarak düzenlemek ve yürütmekten üst kademe yöneticilerine karş1 sorumlu" tutulmuşlardır (m. 56). Görüldüğü gibi kanunun bu amir hükmü, yöneticinin hareket alanına bir sınırlama getirmekte ve onun sistemdeki konumuna ilişkin bir tanımlama yapmaktadır.

Türk eğitim sisteminin aşırı merkeziyetçi yapısına karşın, gelişmiş ve gelişmekte olan pek çok ülkede 1990'lı yılların hemen başında eğitimde yerelleşme eksenli reformlar hayata geçirilmiştir (Luengo, Sevilla ve Torres, 2005; Bjork, 2004; Bodine, 2005). Bu reformların arka planında, merkezi yönetimin elinde bulunan kimi yetkinin kapsamlı bir şekilde okul yönetimlerine devredilmesi düşüncesi bulunmaktadır. Söz konusu reform süreci ile birlikte "okula-dayalı yönetim (ODY)" anlayışı eğitim yönetimi alanında hakim bir anlayışa dönüşmüsstür (Eskeland ve Filmer, 2007; Beck ve Murhpy, 1998).

ODY'nin, gelişimi ile beraber, eğitim yönetimi alanındaki normatif liderlik kuramlarında bir artış gözlenmiştir (Davies, Ellison ve BowringCarr, 2005; Langley ve Jacobs, 2006; Grace, 1995; Bennett ve diğerleri, 2003; Boyd; 2002; MacBeath, 1998; English, 2005; Marion, 2002). Eğitimde normatif liderlik kuramları, okul yöneticisinin yetkilendirilmesi anlayışının gelişimine katkı sağlamıştır. Bu süreçte temel amaç, merkeziyetçi yönetim anlayışında temel işlevi kendisine verilen emirleri uygulamakla sınırlandırılmış yöneticiyi, amaç, hedef ve stratejiler geliştiren ve örgütü bu yönde harekete geçirebilen bir lidere dönüştürmektir (Bush ve Bell, 2002: 3; Bush, 2008). Yöneticinin konumunda ve rolünde gözlenen bu paradigma değişimi, MEB'in teşkilat kanunu referans alındığında, çağdaş gelişmelerden ne kadar uzak olduğunun bir göstergesi olarak düşünülebilir. 
Türkiye'deki eğitim kurumlarında görev yapan yöneticilerin edilgen konumlanışının hukuksal arka planında, kamuda çalışan yöneticilerin "memur" statüsünde istihdam ediliyor olması bulunmaktadır. Memur sözcüğü Arapça "emr" kökünden türetilmiş olup, emir almış, görevli, yükümlü anlamına gelmektedir (Bozkurt ve Ergun, 1998: 164). MEB'in çeşitli kademelerinde görev yapan yöneticiler de devletin memurudur ve kendilerine verilen emirleri yerine getirmekle yükümlüdür.

Memurluk, Türk kamu personel rejiminin temelini oluşturmaktadır. Memurluk mesleği, Anayasanın 128. maddesinde tanımlanmaktadır. Bu madde "devletin kamu iktisadi teşebbüsleri ve diğer kamu tüzel kişilerinin genel idare esaslarına göre yürütmekle yükümlü oldukları kamu hizmetlerinin gerektirdiği asli ve sürekli görevler memurlar ve diğer kamu görevlileri eliyle görülür" şeklinde bir memur tanımlaması yapmıştır. Türkiye'de kamu personel rejimini düzenleyen ve 1965 yılında yürürlüğe girmiş bulunan 657 sayılı Devlet Memurları Kanununa (DMK) göre ise memur "mevcut kuruluş biçimine bakılmaksızın devlet ve diğer kamu tüzel kişilerince genel idare esaslarına göre yürütülen asli ve sürekli kamu hizmetlerini ifa ile görevlendirilenler" biçiminde tanımlanmıştır (m. 4). Şu halde gerek anayasa ve gerekse DMK'de yer alan tanımlardan anlaşılacağ 1 üzere memur, kendisine verilen emirleri uygulamakla yükümlü bir işgörendir.

DMK'nin üçüncü maddesi, memurluk mesleğinin temel ilkelerini "sınıflandırma, kariyer ve liyakat" olarak belirlemiştir. Buna göre devlet memurları on farklı sınıf içerisinde sınıflandırılmıştır. Bu sınıflardan biri de "eğitim ve öğretim hizmetleri” sınıfıdır. Bu sınıf içerisine "eğitim ve öğretim görevi ile görevlendirilmiş olan öğretmenler" girmektedir. Nitekim Türk eğitim sisteminin herhangi bir kademesine yönetici olarak atanabilmenin ön koşulu öğretmen olmaktır.

Bu ilkenin çıkış noktasını 1926 yılında yürürlüğe girmiş bulunan 789 sayılı Maarif Teşkilatı'na Dair Kanun oluşturmaktadır. Kanunun 12. maddesi "meslekte asıl olan öğretmenliktir" hükmünü öngörmüş olup bu anlayış etkisini günümüzde de devam ettirmektedir. Bu anlayışın en somut yansımasını 1739 sayılı Milli Eğitim Temel Kanununda görmek mümkündür. Kanunun 43. maddesine göre öğretmenlik "devletin eğitim, öğretim ve bununla ilgili yönetim görevlerini üzerine alan bir ihtisas alanı"dır. Başka bir ifade ile yönetici olmak için öncelikli olarak öğretmen olmak gerekmektedir.

Türkiye'de eğitim ve okul yöneticisinin hizmet öncesinde yetiştirilmesi ve göreve atanması uzun yıllar boyunca akademisyenler ve eğitimciler 
arasında önemli bir tartışma konusu olmuştur. Tartışmaların odağını, yukarıda verilen kanun hükümleri ile de bağlantılı olarak eğitim ve okul yöneticiliğinin öğretmenlikten bağımsız ayrı bir meslek olup olmadığ 1 olușturmaktadır. Tartışmanın bir diğer boyutunu ise yöneticilerin hizmet öncesi eğitimi ve göreve atanma koşullarının neler olması gerektiği oluşturmaktır.

Şimşek (2002) Türkiye'de eğitim yöneticisi yetiştirme uygulamalarının üç yönlü bir seyir izlediğini ifade etmektedir. Bunlar sırasıyla çıraklık modeli, eğitim bilimleri modeli ve 1999 y1lında MEB tarafindan uygulamaya geçen yönetici atamalarında bazı ek niteliklerin atamalarda tercih nedeni olarak kullanılması modelidir. $\mathrm{Bu}$ model ile beraber, okul yöneticisi seçimine "sınav usulü" getirilmiş ve ilk seçme sınavı 1998 tarihinde yapılmıştır. Sınava 34.505 aday katılmış bu adaylardan 1553'ü başarılı olmuştur. Başarılı olan adaylar daha sonraki süreçte bir hizmet içi eğitim programına devam etmiş ve eğitim sonrasında yeni bir sınava alınmışlardır. Bu sınava katılan 1553 aday, almış oldukları puanlara göre derecelendirilmiş ve ardından boş bulunan okullara müdür olarak atanmışlardır (MEB, 1999: $58)$.

Türkiye'de okul müdürlüğü için ilk kez uygulanan sınav uygulaması daha sonraki süreçte yapılan kimi düzenleme sonucunda bazı değişikliklere uğramış ve daha sonra tamamen kaldırılmıştır. Bu durum eğitim yöneticisi seçme ve yetiştirme usulünde bir eskiye dönüş süreci başlatmış ve akademisyen ve eğitimciler arasında süregelen tartışmaları yeniden alevlendirmiştir.

Türk eğitim sisteminde yönetim görevlerine atanacaklarda aranacak nitelik ve diğer şartlar, kanun gereği MEB tarafından yürürlüğe konulması öngörülen yönetmelik ile düzenlenmektedir (3797 m. 56). Kanunun bu maddesine dayanarak bakanlık, 24.04.2008 tarihinde ve 26856 sayılı Resmi Gazete yayımlanan Milli Eğitim Bakanlığı Eğitim Kurumları Yöneticileri Yönetmeliğini yürürlüğe koymuştur.

Yönetmeliğin, "yönetici olarak atanacaklarda aranacak genel şartlar" başlıklı 11. maddesi incelendiğinde yönetici olarak atanabilmek için aranan koşullar arasında "yönetim alanında eğitim görmüş" olmak koşulunun bulunmadığ 1 görülmektedir. Ancak aynı maddenin müdürlüğe atanma ile ilgili 12. maddesinde, yönetmeliğin ekinde yer alan "Ek-2: Yönetici Değerlendirme Formu"na atıfta bulunulmaktadır. İlgili form incelendiğinde, müdür olmak isteyen adayların yönetim bilimleri alanında yüksek lisans ya da doktora yapmış olmalarına ek puanlar verildiği görülmektedir. Bu 
uygulamaya dayalı olarak yöneticilik eğitimi almış olmanın göreve atanmada bir koşul değil, tercih nedeni olduğu anlaşılmaktadır.

Bu tartışmadan da anlaşılacağı üzere Türkiye'de eğitim yöneticiliğinin özerk bir meslek olarak gelişmesinin önündeki engellerden birinin yürürlükteki yönetici atama yönetmeliği olduğu sonucuna varılabilir. Çünkü mevcut düzenlemeye göre Türkiye'de eğitim ve okul yöneticisi olmak için eğitim yönetimi alanında eğitim almak bir koşul değil tercih nedenidir. Oysa başta ABD, Avustralya ve İngiltere olmak üzere gelişmiş pek çok ülkede okul müdürü adaylarının yöneticilik ve liderlik konulu çeşitli eğitimlerden geçmiş olmaları bir zorunluluktur (Bush ve Bell, 2002: 5; Şişman ve Turan, 2002). Şu halde yönetici atamaya ilişkin mevcut düzenlemeye dayalı olarak Türkiye'de eğitim yöneticiliği ile öğretmenliğin ayrı birer meslek olduğu gerçeğinin henüz tam olarak yerleşmemiş olduğu sonucuna ulaşmak mümkündür.

Diğer yandan, mevcut yönetici atama yönetmeliği, DMK'nin üçüncü maddesinde anılan ve memurluk mesleğinin temel ilkelerinden birini oluşturan "liyakat" ilkesiyle de çelişmektedir. "Liyakat" kavramı Arapça kökenli Osmanlıca bir sözcüktür. Bu sözcük layık, uygun ve yeterli olma anlamına gelmektedir. "Layık" sözcüğü ise nitelik, eylem ve davranışlarıyla bir şeyi elde etmeye hak kazanmış kişiyi tanımlamakta kullanılmaktadır. DMK'de anılan liyakat ilkesi, kimi ön kabuller ve varsayımlara dayanmaktadır. Bu ön kabul ve varsayımlardan biri de, kamu hizmetlerinin etkin ve verimli bir biçimde yerine getirilmesidir. Kamu hizmetlerinin etkin ve verimli bir biçimde yerine getirilmesi ise ancak bu hizmetleri yürütmek üzere görevlendirilen kişilerin (memurların) yeterlik düzeylerine bağlıdır. Dolayısıyla liyakat ilkesini, yeterliğin, kamu örgütlerinde egemen kılınması çabası olarak da tanımlamak mümkündür (Bozkurt ve Ergun, 1998: 158). Bu durumda mevcut yönetici atama yönetmeliği, DMK'nın temelini oluşturan liyakat ilkesini zedelemekte olup, yeniden ele alınıp düzenlenmesi gerekmektedir.

\section{Eğitim Yöneticisinin Yetki, Görev ve Sorumlulukları}

Okul, "öğrencilerini, önceden tasarlanmış eğitsel amaçlara ulaştırmak için gereken davranışı (bilgi, beceri ve tutumu) planlı bir süreç içinde ve belli bir sürede kazandıran örgüttür" (Başaran, 2006: 138). Okul yönetiminin görevi ise "okuldaki tüm insan ve madde kaynaklarını en verimli şekilde kullanarak, okulu amaçlarına uygun olarak yaşatmaktır" (Taymaz, 2003: 55). On birinci Milli Eğitim Şurasına göre eğitim yöneticinin görevi “...okullarda...eğitim programlarını, öğrenci hizmetlerini, işgören hizmetlerini, bütçe işlerini, eğitim bina, araç ve gereçlerine ilişkin işleri" yönetmektir. 
Türkiye'de okul sistemi yapılanması pek çok ülkede olduğu gibi okul öncesi eğitim, ilköğretim, ortaöğretim ve yüksek öğretim olmak üzere dört basamaklı bir sistemden meydana gelmektedir. Bu düzenleme, 1973 y1lında yürürlüğe girmiş bulunan 1739 sayılı Milli Eğitim Temel Kanunu'na dayalı olarak gerçekleştirilmiştir. Bu kanuna dayalı olarak yüksek öğretim hariç olmak üzere her bir eğitim kademesinin işleyişini düzenleyen yönetmelikler hazırlanıp yürürlüğe konulmuş ve bu yönetmeliklerde okul yöneticilerinin yetki, görev ve sorumlulukları sıralanmıştır. Her bir eğitim kademesi kendine özgü bir takım özellikler sergilemesine karşın yöneticilerin görev ve sorumluluk alanları genelde benzerlikler göstermektedir.

Örneğin, yürürlüğe 1964 tarihinde giren ve günümüze kadar 31 kez değişikliğe uğrayan Lise ve Ortaokullar Yönetmeliğine göre okulu müdür yönetir (R.G. 28.11.1964, Say1: 11868). Müdüre yönetim işlerinde müdür yardımcıları, öğretmenler ve stajyer öğretmenler yardım eder (m. 5). Benzer şekilde, 2003 yılında yürürlüğe giren Milli Eğitim Bakanlığı İlköğretim Kurumları Yönetmeliğinin 60. maddesine göre ilköğretim okulunu "demokratik eğitim öğretim ortamında diğer çalışanlarla birlikte müdür yönetir". Bu madde müdürü, okulun amaçlarına uygun olarak yönetilmesinden, değerlendirilmesinden ve geliştirmesinden de sorumlu tutmaktadır. Aynı madde uyarınca okul müdürü; ders okutmanın yanında kanun, tüzük, yönetmelik, yönerge, program ve emirlere uygun olarak görevlerini yürütmeye, okulu düzene koymaya ve denetlemeye yetkilidir. Müdür, okulun amaçlarına uygun olarak yönetilmesinden, değerlendirilmesinden ve geliştirmesinden de sorumlu tutulmuştur.

Türkiye'de değişik kademe ve türdeki eğitim kurumlarında görev yapan müdürlerin görev ve sorumluluklarını dörtlü bir sınıflandırma içerisinde incelemek mümkündür (Taymaz, 2003). Bunlar personel, öğrenci, eğitim ve öğretim ve okul işletmeciliği ile ilgili görevlerdir. Okul yöneticisinin temel rolü daha önce de belirtildiği gibi, bu işleri başta Anayasa olmak üzere ilgili kanun, tüzük, yönetmelik ve yönergelere dayalı olarak planlamak, uygulamak ve denetlemektir. Aşağıda okul yöneticilerinin bu görevleri tartışılmıştır.

\section{Personel İşleri}

Okul müdürünün personel işleri ile ilgili görevleri, atanan personelin göreve başlatılması, stajyerlik ve adaylık işlemlerinin yapılması, personel özlük haklarının sağlanması, sicil ve disiplin işlerinin yürütülmesi, sağlık, güvenlik ve askerlik işlerinin yapılması ve devamı, izleme ve denetimi gibi geniş bir yelpazede incelenebilmektedir. Okul müdürünün göreve yeni atanan personel ile ilgili yapacağ işler arasında ise atanan personelin göreve 
başlatılması, atanan personel için belgelerin düzenlenmesi, personelin görev, yetki ve sorumluluklarının belirlenmesi, nakil ve yer değiştirme ile ilgili işlemlerin yapılması ve görevden ayrılan personelin işlemlerin yapılması bulunmaktadır. Müdür ayrıca, bakanlığa bağlı okullara yeni atanan stajyer sınıf ve branş öğretmenleri ile aday memurların bağımsız görev yapabilecek yetkinliğe ulaşmaları, gerekli yeterlikleri kazanmaları için hizmet içinde yetiştirir ve çalışmalarını değerlendirir (Taymaz, 2003: 100).

Müdürün personel işleri ile ilgili bir diğer görevi ise personelin özlük haklarını sağlamasıdır. Özlük işleri, genel olarak memurların "hizmet yaşantılarına ilişkin iş, işlem ve hizmetlerin bütünü olarak" tanımlanmaktadır (Bozkurt ve Ergun, 1998: 196). Özlük işleri bir kayıt sistemine dayanmaktadır. Bu kayıt sisteminin özünü özlük ve sicil dosyaları oluşturmaktadır. Devlet Memurları Sicil Yönetmeliğine (1986) göre özlük dosyasında memurun kişisel kimliği ve memurluk özgeçmişiyle ilgili bilgi ve belgeler yer almaktadır (m. 6). Sicil dosyası ise gizli sicil raporları ile varsa müfettiş raporları ve mal bildirimlerini içermektedir (m. 7).

Müdürün okulda çalışan öğretmen ve diğer memurların özlük haklarının sağlanması ile ilgili olarak, personelin ilerleme ve yükselme ile ilgili işlerin yapılması, maaş ve ücretlerinin ödenmesi, kimi diğer yardımların ödenmesi (yolluk, doğum, tedavi, ölüm ve cenaze vb), izin verilmesi (yıllık, mazeret, hastalık ve aylıksız) ve emeklilik işlemlerinin yapılması gibi görevleri bulunmaktadır (Taymaz, 2003: 109-115).

$\mathrm{Bu}$ görevlere ek olarak okul müdürü, okulda düzeni sağlamak ve personelin, iş ve işlemleri mevzuata göre yapmalarını sağlamak amacıyla disiplin işlerini de yürütmektedir. Memurların birlikte bulunmasının ve düzenli olarak çalışmalarının sağlanabilmesi için uygulanan yaptırımlara disiplin cezası denilmektedir. Daha değişik bir ifade ile bir kurumda çalışan memurların, kurumun düzenini bozucu davranışlarına karşı uygulanan yaptırımlar disiplin cezası olarak isimlendirilmektedir (Gözübüyük, 2002: 210).

Genel olarak kamu hizmetlerinin görülmesi esnasında memur ve diğer kamu görevlileri diğer kişilere ve bazen de devlete zarar verebilirler. $\mathrm{Bu}$ bağlamda disiplin hukuku, fiillere uyan adli nitelikli işlemlerle birlikte ayrıca, kamu görev hizmetlerinin sağlıklı, düzenli, zamanında ve gereği gibi yürütülüp yerine getirilmesini sağlamak için, kanun, tüzük, yönetmelik ve diğer mevzuat ile görevleri belirlenen memurlara görevlerini gereği gibi yapmamaları durumunda uygulanacak işlemleri kapsamaktadır (Çiftçi, Türkmen ve Türkmen, 2004: 389). 
DMK'nin 125. maddesi uyarınca memurların kusurlu davranışlarına bağlı olarak varsa öncelikle özel kanunlara göre, değilse yine kanunun aynı maddesinde yer alan cezalardan birisi ile cezalandırılacağ 1 hükme bağlanmıştır. Türk eğitim hukukunda eğitim işlerini gören yönetici ve öğretmenlerin disiplin işlerini düzenleyen kanunlardan biri 1702 Sayılı İlk ve Orta Tedrisat Muallimlerinin Terfi ve Tecziyeleri Hakkında Kanundur. Yürürlüğe 1930 yılında girmiş bulunan kanun, okul müdürü, müdür başyardımcısı, öğretmen ve ilköğretim müfettişlerine işlemiş oldukları suçun içeriği ve derecesine göre on farklı türde ceza verilmesini hükme bağlamıştır. $\mathrm{Bu}$ cezalar sırasıyla ihtar (uyarma), tevbih (kınama), ders ücretlerinin kesilmesi, maaş kesilmesi, kıdem indirilmesi, derece indirilmesi, istifa etmiş sayılmak, bakanlık emrine alınmak, meslekten çıkarılmak ve devlet memurluğundan çıkarılmaktır (m. 19).

DMK'nın 126. maddesine göre uyarma, kınama ve aylıktan kesme cezaları disiplin amirleri tarafindan; kademe ilerlemesinin durdurulması cezası, memurun bağlı olduğu kurumdaki disiplin kurulunun kararı alındıktan sonra atamaya yetkili amirler, il disiplin kurullarının kararlarına dayanan hallerde ise valiler tarafından verilmektedir. Şu halde okul müdürü okulda çalışan tüm personelin disiplin amiri olması sıfatı nedeniyle okulda düzeni sağlamak amacıyla uyarma, kınama ve aylıktan kesme cezalarından birini verebilme yetkisine sahiptir.

Okul müdürünün bir diğer önemli görevi, öğretmenleri denetlenmesi ve onlara rehberlik etmesidir. Eğitim faaliyetlerinin denetlenmesinin yasal dayanağını Anayasanın 42. maddesi oluşturmaktadır. Bu madde "eğitim ve öğretim, Atatürk ilkeleri ve inkılapları doğrultusunda, çağdaş bilim ve eğitim esaslarına göre, devletin gözetim ve denetimi altında yapılır" hükmünü öngörmektedir. Dolayısıyla okul müdürünün denetim yapma görevi anayasal bir haktır.

Yöneticinin öğretmenleri denetlemesine ilişkin hükümleri çeşitli yönetmeliklerde de görmek mümkündür. Örneğin, Lise ve Ortaokullar Yönetmeliğinin yedinci maddesi müdürün "ders y1lının çeşitli zamanlarında öğretmenlerin derslerini yakından izlemekten" sorumlu olduğunu belirtmektedir. Benzer şekilde MEB Mesleki ve Teknik Eğitim Yönetmeliği de (R.G. 03.07.2002, Sayı: 24804) yöneticinin görevlerinden birinin personelin performansının değerlendirilmesi olduğunu hükme bağlamıştır. İlgili yönetmeliğe göre yöneticinin denetim kapsamındaki asli görevleri arasında personele mesleki yardım ve rehberlik yapması da bulunmaktadır. Yöneticinin denetim görevinin bir anlamda personelin mesleki gelişimine rehberlik edilmesi anlamını taşıyan bu yönetmelik hükmü, modern denetim ilkeleri ile de uyum göstermektedir. 
Gerçekten de çağdaş anlamda denetim, çalışanların, örgütün amaçlarını başarmasına dönük eylemlerine rehberlik edilmesi biçiminde tanımlanmaktadır (Daresh, 2001: 25). Okulun önceden belirlenmiş eğitsel amaçlarına ulaşabilmesi büyük oranda eğitim ve öğretim işlerini yürüten öğretmenlerin mesleki beceri ve yeterliklerinin geliştirilmesine bağlıdır. Öğretmenlerin görev başında etkin bir biçimde geliştirilmesinde müdüre büyük sorumluluk düşmektedir. Çünkü denetim süreci, "öğrenci başarısını iyileştirmeye yardım konusunda bir aracılık işlevi görmektedir" (Aydın, 2005: 3). Şu halde okul müdürünün deneticilik rolü öğretmenlerin sonul performanslarını ölçmenin ötesine geçebilmeli ve öğretmenlerin mesleki gelişimlerine de katkı sağlamalıdır (Glickman, 1990: 309).

\section{Öğrenci İşleri}

Öğrenci, planlı öğretim yapan eğitim kurumlarında, önceden tasarlanan bir eğitim programının gerektirdiği öğrenme yaşantılarını belli bir sürede kazanmaya çalışan kişidir (Başaran, 2006: 357). Bir örgüt olarak okulun varlık nedeni ise öğrencilerini, 1739 sayılı Milli Eğitim Temel Kanunun birinci maddesinde sıralanmış amaçlar doğrultusunda yetiştirmektir. Kanunda sıralanmış amaçlar bir tarafindan toplumun ve devletin ihtiyaçlarını karşılamaya dönük iken diğer yandan öğrenciyi hayata hazırlamayı hedeflemektedir.

Milli eğitim sisteminin kademelerini oluşturan okul öncesi eğitimi, ilköğretim, ortaöğretim ve yüksek öğretime ilişkin amaç ve görevler, ilgili öğretim kademesinin özelliklerine göre belirlenmiş ve kanunda ayrı ayrı sıralanmıştır. Kanuna dayalı olarak her bir eğitim kademesinin amaç ve görevlerini nasıl yerine getireceğine ilişkin yönetmelikler hazırlanmış ve yürürlüğe girmiştir. Örneğin, Lise ve Ortaokullar Yönetmeliğinin ikinci maddesine göre liseler, eğitim ve öğretim işlerinde öğrencisinin;

a) Türkiye Cumhuriyetinin, millî ve ahlâki değerlerini benimsemiş ve olumlu bilim anlayışını kazanmış, çalışkan, yararlı bir yurttaşı olarak yetişmesini;

b) Müfredatı programlarla saptanan ve yüksek öğrenimi izlemek için gerekli bulunan bilgi ve kültür düzeyine erişmesini;

c) Bilgilerini uygulama alanında kullanma yollarını öğrenmesini ve ilerde meslek seçmesini kolaylaştıracak surette yeteneklerinin geliştirilmesini;

d) İyi alışkanlıklar, maharetler kazanmasını, ruhça ve bedence sağlam olmasını amaçlamaktadır. 
Yönetmelikte sıralanmış bu amaçların başarılmasında ise okul yöneticisine büyük bir görev düşmektedir. Müdür bu amaçların gerçekleşmesi sürecinde her türlü öğrenci işlerini belirli bir düzen içerisinde yürütmek durumundadır. Diğer yandan yöneticinin, öğrenci işlerini yerine getirirken kimi ilkelere göre hareket etmesi de gerekmektedir. Bu ilkeler 1793 Say1lı Milli Eğitim Temel Kanununda on dört madde halinde sıralanmıştır. Bu ilkeler sırasıyla, genellik ve eşitlik, ferdin ve toplumun ihtiyaçları, yöneltme, eğitim hakkı, fırsat ve imkan eşitliği, süreklilik, Atatürk İnk1lap ve İlkeleri ve Atatürk Milliyetçiliği, demokrasi eğitimi, laiklik, bilimsellik, planlılık, karma eğitim, okul ile ailenin işbirliği ve her yerde eğitimdir. Bu ilkeler Milli Eğitim Bakanlığı İlköğretim Kurumları Yönetmeliğinin 6. maddesinde daha ayrıntılı bir biçimde yeniden ele alınmış olup, müdürün bu temel ilkeler doğrultusunda öğrenci işlerini planlaması ve uygulaması gerekmektedir.

Okullarda öğrenci işleri, öğrenciyi okula alma, sınıflama, devamdevamsızlık durumları, sınavlar ve sınıf geçme sistemi, öğrenci başarılarının tespiti, disiplin işleri, sağl1k, rehberlik, yönlendirme ve öğrenciliğin sona ermesi gibi iş ve işlemlerden meydana gelmektedir (Başaran, 2006: 357). Müdür, siralanan tüm bu işleri belirli bir düzen içerisinde yürütmek durumundadır. Sözü geçen tüm bu öğrenci işlerinin nasıl yapılacağı ayrıntılı bir biçimde gerek Milli Eğitim Bakanlığ İlköğretim Kurumları Yönetmeliği ve gerekse Lise ve Ortaokullar Yönetmeliğinde açıklanmıştır.

$\mathrm{Bu}$ yönetmeliklere ilave olarak çıkartılmış kimi yönetmelikler de öğrenci işlerinin nasıl yapılacağını ayrıntılı bir biçimde anlatmaktadır. Örneğin, yürürlüğe 2007 y1lında girmiş bulunan Milli Eğitim Bakanlığ1 Ortaöğretim Kurumları Ödül ve Disiplin Yönetmeliği, MEB'e bağlı resmi ve özel örgün eğitim-öğretim veren ortaöğretim ödül ve disiplin işlemlerinin nasıl yapılacağına ilişkin usul ve esaslarını düzenlemek amacıyla çıkartılmıştır (m.1).

Yürürlüğe 2004 yılında girmiş bulunan Milli Eğitim Bakanlığı Ortaögretim Kurumları Sınıf Geçme ve Sınav Yönetmeliği ise MEB'e bağlı resmi ve özel orta öğretim kurumlarında sınıf geçme ve sınavlarla ilgili usul ve esasları düzenlemek amacıyla çıkartılmıştır (m. 1). Sözü geçen her iki yönetmelikte okul yöneticilerinin öğrencilerin ödül ve disiplin işleri ile sınıf geçme ve sınav işlemlerinin nasıl yönetmeleri gerektiğini düzene sokmaktadir. 


\section{Eğitim ve Öğretim İşleri}

Bir kurum olarak okulun varlık nedeni, eğitim ve öğretim etkinliklerinin planlı bir biçimde uygulanmasıdır. Bir bakıma okul, eğitim girişiminin düzenlendiği özel bir çevredir. Özel bir çevre olarak okul, çevrede olmayıp ancak istenen ya da çevrede olup da istenmeyen kavram ve süreçlerin kontrol edilmesi ihtiyacı sonucu ortaya çıkmıştır (Bursalığlu, 2002: 34). Dewey'e göre okulun eğitim girişimindeki temel rolü, basitleştirme, temizleme ve denge kurmaktır (Tezcan, 1996: 257). Dolayısıyla okulda yapılan eğitim ve öğretim etkinliklerinin temel amacı özel olarak yaratılmış bir çevre içerisinde öğrencilerin eğitilmesidir.

Toplumlar kendilerine uygun insanı kendilerine özgü bir eğitim süreci içinde yetiştirler. Yetiştirme süreci ise tesadüflere ve kültürlemenin gelişigüzel etkilerine bırakılmadan okul denilen kurumlarda yapılmaktadır. $\mathrm{Bu}$ nedenlerden dolayı okulda yapılan eğitim formaldir. Eğitimin formal olmasından kasıt, eğitim girişiminin belli amaçlar doğrultusunda önceden hazırlanmış programlara göre yürütülmesidir. Okulda eğitim ve öğretim etkinlikleri planlı bir biçimde başta müdür olmak üzere diğer eğitim işgörenleri tarafindan yerine getirilmektedir (Fidan ve Erdem, 1998: 14).

Okullarda eğitim ve öğretim etkinliklerinin planlaması, uygulanması ve denetlenmesinden müdür sorumludur. Müdürün eğitim ve öğretim ile ilgili temel görevlerinin başında, okulun y1llık öğretim planını hazırlaması gelmektedir. Planlama, okulun sahip olduğu madde ve insan kaynaklarının göz önünde bulundurularak, okulu gelecek yıllarda ulaşmak istediği hedeflerin, politikaların ve izlenecek stratejilerin belirlenmesi süreci olarak tanımlanmaktadır (Şişman ve Taşdemir, 2008: 238).

$\mathrm{Bu}$ anlatılanlar 1şığında müdürün öğretim ve program geliştirme konusunda önemli bir rol oynadığını söylemek mümkündür. Nitekim müdürün en önemli görevlerinden biri de öğretim ve program geliştirmektir. $\mathrm{Bu}$ süreçte müdürden, program hedeflerini belirlemesi, program içeriğini belirlemesi ve örgütlemesi, zamanlama yapması, fiziksel olanakları sağlaması, personel bulması, öğretim programı için materyal, kaynak ve donatım sağlaması, öğretimi denetlemesi ve son olarak öğretim personeli için hizmet-içi eğitim olanaklarını sağlaması beklenmektedir (Aydın, 2007: 190).

MEB'e bağlı eğitim kurumlarında, eğitim ve öğretime ilişkin planlar temel olarak zümre öğretmenler kurulu ve şube öğretmenler kurulları tarafından hazırlanmaktadır. Bu kurul çalışmalarında Türk milli eğitiminin genel amaçları, okulun kuruluş amacı ve ilgili dersin programında belirtilen amaçların-hedeflerin başarılmasına dönük planlar yapılmakta ve bu planlar eğitim ve öğretim y1lı içerisinde uygulamaya geçirilmektedir. Müdürün bu süreçteki görevlerini şu şekilde sıralamak mümkündür (MEB, 2007: 41); 
1. Öğretmen ve öğrencileri ilgilendiren konuların zamanında bildirilmesi,

2. Bakanlıkça gönderilenlerin dışında kullanılan film, kaset, ses bandı, disket, $\mathrm{CD}$, vb. eğitim araç-gereci için gerekli onayın alınması,

3. Haftalık ders programının hazırlanmasında, dersin özelliği, ders saati sayısı vb. hususların göz önünde bulundurulması (Lise ve Ortaokullar Yönetmeliği, m.7)

4. Özel derslik, laboratuar, kitaplık ve diğer ünitelerden öğrencilerin eşit düzeyde ve azami ölçüde yararlanabilmeleri için gerekli plânlamanın yapılması,

5. Açık geçen derslerin kapatılması yönünde gerekli önlemlerin alınması,

6. Çeşitli sebeplerle yapılamayan derslerin yoğunlaştırılmış programlarla tamamlanması (Sınıf Geçme ve Sınav Yönetmeliği, m.37),

7. Yetiştirme ve hazırlık kurslarının açılması (Öğrencileri Yetiştirme Kurslar1 Yönergesi-2559 S.T.D.).

MEB Liseler ve Ortaokullar yönetmeliğinin yedinci maddesi uyarınca müdür öğretim işlerini "her hangi bir aksamaya meydan vermeden" yürütmekten sorumludur. İlgili madde uyarınca müdürün öğretim işleri ile ilgili görevlerinden birini, ders yılı başında öğretmenlerden öğretim ile ilgili yıllık bir plan almak, bu planların yıllık raporda tasarlanan zamanlar içinde uygulanıp uygulanmadığını denetlemek ve izlemek, eğitim programlarının bitirilmeyen kısımlarını nedenleriyle birlikte bakanlığa bildirmek oluşturmaktadır. Buna ek olarak müdürün, derslerin birbirleri ile uyumlu bir şekilde okutulmasını ve aynı ders zümresiyle ilgili öğretmenlerle, aynı sınıfta ders veren öğretmenler arasında iş birliği yapılmasını sağlaması da gerekmektedir.

$\mathrm{Bu}$ yönetmeliğe göre müdürün eğitim ve öğretim ile ilgili görevlerinden biri de derslerin verimliliğini artıracak maddi olanakları hazırlamasıdır (m.7). Bu olanaklar arasında okulda bulunan eşya ve ders araç gereçleri ile laboratuar ve işliklerden öğrencilerin yararlanabilmelerini sağlayacak düzenlemelerin yapılması bulunmaktadır. Buna ek olarak müdürün okulda bulunmayan kimi ders araçlarını sağlama yoluna gitmesi ve öğretmenlerin bu araçları kullanmalarını ve öğrencilerine de kullandırmaları işlerini izlemek gibi bir görevi de bulunmaktadır. Okul müdürü ayrıca öğrencilerin öğretmenleriyle birlikte yapacakları doğa, çevre ve teknik kurumları inceleme gezilerini, eski eser ve müzeleri ziyaret gibi çalışmaları da planlamak durumundadır. 
Bu yönetmeliğe göre müdürün eğitim ve öğretim ile ilgili görevlerinden bir diğeri ise ders içi ve dışı çalışmalarda gördüğü eksiklikler ve alınması gereken tedbirler hakkında öğretmenlerle ayrı ayrı görüşmesi ve teftiş sonuçlarını saptayarak bu amaçla hazırlanmış olan basılı raporları işlemesidir (m. 7). İlgili madde uyarınca müdür aynı zamanda öğrencilerin laboratuar, atölye ve kitaplıklardan yararlanmaları için öğretmenlerin almış oldukları önlemleri yakından izlemekle mükelleftir. Müdürün eğitim ve öğretim ile ilgili temel görevleri arasında gerek öğrenciler, gerek çevre ile ilgili eğitim, öğretim çalışmaları için, çalışma saatleri dışında da okuldan yararlanılması olanaklarını sağlamak, bu arada evlerinde çalışabilme olanağ 1 bulamayan öğrenciler için, okul-aile birliği ile işbirliği bulunmaktadır.

Yine aynı yönetmeliğe göre müdürün temel görevi eğitim ve öğretim ortamını hazırlamak, gerekli ders araç ve gerecini temin etmek, öğretmenlerin yapmış olduğu öğretim etkinliklerini denetlemek ve okulun ders saatleri dışında da kullanılmasını sağlayacak tedbirler almaktır. Görüldüğü üzere mevzuat uyarınca müdürün eğitim ve öğretim konusundaki temel rolü öğretim etkinliklerine destek hizmeti sunmak ve bu etkinliklerin belirli plan çerçevesinde yerine getirilmesini sağlamaktır. Oysa bu yönde yapılan akademik çalışmalar müdürün artık geleneksel rolünden sıyrılıp, bir öğretim lideri olması gerektiği yönünde birleşmektedir.

Öğretimsel liderlik, sınıftaki öğretimi olumlu etkileyecek günlük süreçleri sürekli bir şekilde yönetmek ve desteklemek biçiminde tanımlanmaktadır (Liu, 1984). Öğretimsel liderlik, öğretmenlere verimli ve doyurucu bir çalışma ortamı ve öğrencilere arzu edilen öğrenme ortamları ve çıktıları oluşturmak için atılan adımlarla yakından ilişkilidir (Knezek, 2001). Günümüzde etkili okulların temel parametrelerinden birinin etkili yönetici olduğu öne sürülmektedir. Etkili yöneticilerin ise etkili öğretim lideri oldukları yönünde genel bir kabul bulunmaktadır. Etkili öğretim liderlerinin öğretim konusuna öncelik verdikleri, öğretime ilişkin amaç ve beklentilerini açık ve seçik olarak ortaya koydukları, zamanlarının çoğunu öğretim sorunları ile ilgilenerek geçirdikleri, öğretime ilgi ve destek verdikleri ve personel ile yakın işbirliği içerisinde oldukları ifade edilmektedir (Balcı, 2001: 127). Dolayısıyla günümüzde müdürlerden, eğitim öğretim etkinliklerine destek hizmeti sunmanın ötesinde, bu etkinliklere rehberlik edecek ve geliştirecek etkili liderlik davranışları sergilemesi de beklenmektedir. 


\section{Okul İşletmeciliği}

Özelleştirme ve liberal anlayışın eğitimi de etkisi altına alması ile birlikte, liberal ekonominin kavramları, giderek eğitim ve okullar için de kullanılmaya başlamıştır. Bu çerçevede okul, artık bir işletme olarak ele alınıp incelenmeye başlamıştır (Şişman ve Taşdemir, 2008: 258). Bu anlayışın bir sonucu olarak geleneksel olarak bürokratik bir anlayışla örgütlenen ve yönetilen okullar, günümüzde artık özel bir işletme gibi yönetilme süreci içerisine girmişlerdir (Özdemir, 2008c). Okul yönetiminde gözlenen bu paradigma değişimi okul müdürünün geleneksel rolünde de bir değişmeye yol açmış ve yeni dönemde okul müdürleri "kamu yöneticisi" kimliğini "işletmeci" kimliği ile değiştirmek durumunda kalmıştır (Grace, 1995: 5).

Okul işletmeciliği genel olarak "eğitim için kullanılacak bina, tesis ve araçların sağlanması, hazır bulundurulması ve çalıştırılması etkinliklerini" örten şemsiye bir kavramdır (Taymaz, 2003: 215). Gerçekten de okulların eğitsel amac1 gerçekleştirebilmesi büyük oranda etkili işletilip işletilmedikleri ile yakından ilgilidir. Okul işletmesi ile ilgili işler ise okul müdürlerinin görev alanları içerisinde önemli bir yer tutmaktadır. Sözü geçen işler arasında okulun bütçesi, okulda yazı işleri, veri işleme ve raporlar, satın alma ve mal tedarik işleri, okul bina ve tesislerinin bakım, onarım ve kullanılması işleri, temizlik işleri, okul bahçesinin düzenlenmesi, taşınır mallarla ilgili işler, sivil savunma ve güvenlikle ilgili işlemler, öğrenci taşıma hizmetleri, öğrenci pansiyon hizmetleri, kooperatif işleri, kantin işleri, döner sermaye işleri, arşiv hizmetleri ve depolar ile ilgili hizmetler bulunmaktadır (Şişman ve Taşdemir, 2008: 258-284).

MEB Liseler ve Ortaokullar Yönetmeliği müdürü, okulun bina ve eşyasının korunması, iyi kullanılması, temizliği ve düzeninin sağlanması ve ilgili ödev sahiplerinin yakından izlenilmesi ile yükümlü tutmaktadır (m. 6). Ancak günümüzde müdürün okul işletmesi ile ilgili görevleri fiili olarak bu yönetmelikte sıralanan görevlerin çok daha ötesine geçmiştir. Yukarıda da söz edildiği gibi ekonomide liberal yaklaşımların etkisi ile birlikte okul müdüründen artık bir işletme yöneticisi rolü oynaması beklenmektedir. Bilindiği gibi kar amacı güden işletmelerin etkililiğini artırmak üzere geliştirilen toplam kalite yönetimi (TKY) gibi yeni yönetim yaklaşımları 1990'lı yıllarla birlikte okul yönetimi alanına da taşınmış (Ensari, 1999: 20) ve okul yönetiminde egemen bir anlayış haline gelmişlerdir.

TKY ve diğer yeni yönetim yaklaşımlarının sonul amacı yoğun rekabet baskıs1 altındaki örgütleri (işletmeleri) daha etkili yönetmektir. $\mathrm{Bu}$ gelişmelerin bir doğurgusu olarak okul yöneticisinden okulu TKY anlayışına 
göre yönetmesi genel bir kurala dönüşmüştür. $\mathrm{Bu}$ yönde atılmış somut adımlardan biri 1999 yılında yürürlüğe girmiş bulunan Milli Eğitim Bakanlığ 1 Toplam Kalite Yönetimi Yönergesidir. Yönerge, MEB'e bağlı merkez, taşra ve yurtdışı örgütleri ile bağlı kurumlarda yürütülen faaliyetlerin TKY anlayışı çerçevesinde yürütülmesini emretmektedir (m. 1).

Kuşku yok ki TKY'nin okullarda uygulanmasından birinci derecede sorumlu işgören okulun müdürüdür. $\mathrm{Bu}$ süreçte okul müdürleri, okulu bir işletme gibi algılamaya başlamış ve okulu yaşatabilmek amacıyla çeşitli kaynaklar yaratmak yoluna girmişlerdir. Bunlar arasında, okul bahçelerinin oto parklara çevrilmesi, okul güvenliği, okul temizliği, boya ve badana işlerinin velilerden toplanan bağışlarla karşılanır hale getirilmesi göze en fazla çarpan uygulamalardır (Sezen, 1999: 227).

\section{SONUÇ}

Bu çalışmada temel olarak okul sisteminin temel unsurlarından biri olan okul yöneticilerinin göreve atanma usulü ile yetki, görev ve sorumluluk alanları, yürürlükteki eğitim mevzuatı referans alınarak incelenmiştir. İnceleme sürecinde, okul yöneticiliğini konu edinen alanyazına dayalı olarak mevcut durum ile olması gereken durumun bir karşılaştırılması yapılmıştır. Böylece, eğitim yöneticilerin eğitim mevzuatında tanımlanmış bulunan yetki, görev ve sorumluluk alanları eleştirel bir perspektifle irdelenmiş ve sonuçta okul yöneticiliğine ilişkin sorun alanları keşfedilmeye çalış1lmıştır.

Çalışmada öncelikli olarak okul yöneticilerin hizmet öncesinde yetiştirilmeleri ve göreve atanma biçimi ele alınmış ve bu konu ile ilgili olarak kimi ülkelerde son yıllarda gözlenen uygulamalar tartışılmıştır. Yapılan çözümlemede, Türkiye'de eğitim yöneticiliğine atanmayı düzenleyen mevzuatın, liyakat ilkesi ile çeliştiği sonucuna ulaşılmıştır. Çünkü yürürlükteki uygulama, hizmete alınmada yöneticilik eğitimi sertifikasına sahip olmayı bir koşul değil; bir tercih nedeni olarak görmektedir. $\mathrm{Bu}$ durum aynı zamanda okul yöneticiliği alanının öğretmenlikten özerk bir meslek olarak gelişmesini engellemektedir. Bu uygulamanın kökeninde "meslekte asıl olan öğretmenliktir" ilkesi bulunmaktadır. Bu ilkenin ve bu ilkeye dayalı yönetici atama usulünün terk edilmesi, okul yöneticiliği alanının özerk bir meslek haline gelmesine katkı getireceği bu çalışmada ortaya çıan en önemli sonuçlardan biridir.

Çalışmada ayrıca okul yöneticilerin yetki, görev ve sorumluluk alanlarının personel, öğrenci, eğitim-öğretim ve okul işletmeciliği ile ilgili işlerden oluştuğu görülmüştür. Ayrıntıları metin içerisinde tartışılmış olan ve 
bu alanları düzenleyen mevzuatın, eğitim yönetiminde son yıllarda gözlenen değişim sürecinin oldukça gerisinde kaldığı bu çalışmanın bir diğer önemli sonucudur. Eğitim yönetimi alanındaki genel eğilim, okul yöneticilerinin okula dayalı yönetim anlayışı çerçevesinde yetkilendirilmeleridir. Buna bağlı olarak, yöneticilerin, dikey örgütsel iletişimin bir gereği olarak kendilerine verilen emirleri uygulamanın ötesinde geçerek, okulun etkililiğini artıracak stratejiler geliştiren bir lidere dönüşmeleri genel bir beklentiye dönüşmüştür. Oysa bu çalışmada da görüldüğü gibi, mevcut uygulamanın okul yöneticisinden beklediği temel rol, okulu, yürürlükteki mevzuatın çizdiği sinırlar içerisinde yönetmesidir.

\section{KAYNAKLAR}

Aydın, İ. (2005). Öğretimde Denetim: Durum Saptama, Değerlendirme ve Geliștirme. Ankara: PegemA Yayıncılık.

Aydın, M. (2007). Ĕğitim Yönetimi. (Genişletilmiş Sekizinci Baskı). Ankara: Hatipoğlu Basım ve Yayım Tic. Ltd. Şti.

Balc1, A. (1988). Eğitim Yöneticisinin Yetiştirilmesi. Ankara Üniversitesi Eğitim Bilimleri Fakültesi Dergisi, 21(1), 435-448.

Balc1, A. (2001). Etkili Okul ve Okul Geliştirme: Kuram, Uygulama ve Araştırma. Ankara: PegemA Yayıncılık.

Başaran, İ. E. (2000). Eğitim Yönetimi: Nitelikli Okul. Ankara: Feryal Matbaas1.

Başaran, İ. E. (2006). Türk Eğitim Sistemi ve Okul Yönetimi. Ankara: Ekinoks Yayınc1lk.

Beck, L. G., Murpyh, J. (1998). Site-Based Management and School Success: Untangling the Variables. School Effectiviness and School Improvement, 9, 358-385.

Bennett, N., Crawford. M., Cartwright, M. (2003). Effective Educational Leadership. London: Paul Chapman Publishing.

Bjork, C. (2004). Decentralization in Education, Institutional Culture and Teacher Autonomy in Indenosia. International Review of Education, 50, 245-262.

Bloom, B. J. (1998). Insan Nitelikleri ve Okulda Öğrenme. (Çeviren. Durmuş Ali Özçelik). İstanbul: Milli Eğitim Basımevi.

Bodine, E. F. (2005). Radical Decentralization and the Role of Community in Polish Educational Reform. European Education, 37(1), 83-102.

Boyd, P. W. (2002). Educational Leadership. California: ABC-CLIO Publishing.

Bozkurt, Ö. Ergun, T. (1998). Kamu Yönetimi Sözlüğ̈̈. Ankara: TODAİE Yayınları. 
Bursalığlu, Z. (2002). Okul Yönetiminde Yeni Yapı ve Davranış. Ankara: PegemA Yayıncilık.

Bush, T., Bell, L. (2002). Principles and Practice of Educational Managament. California: SAGE Publications.

Bush, T. (2008). From Management to Leadership; Semantic or Meaningful Change. Educational Management Administration and Leadership, 36(2), 271-288.

Çiftçi, M., Türkmen, Ş., Türkmen, Ö. (2004). Eğitim Kurumları Müdür Yardımcılığı Sinavlarına Hazırlık. (2. Baskı). Ankara: Alp Yayıncılık.

Daresh, J. C. (2001). Supervision as Proactive Leadership. (3rd Edision). Illinois: Waveland Pres Inc.

Davies, B., Ellison, L., Bowring-Carr, C. (2005). School Leadership in the 21st Century. London: RoutledgeFalmer.

English, F. W. (2005). The Sage Handbook of Educational Leadership. London: SAGE Publications.

Ensari, H. (1999). 21. Yüzyll Okulları İçin Toplam Kalite Yönetimi. İstanbul: Sistem Yayınc1lik.

Eskeland, G., Filmer, D. (2007). Autonomy, Participation and Learning: Findings from Argentine Schools, and Implications for Decentralization. Education Economics, 15(1), 103-127.

Fidan, N. Erden, M. (1998). Eğitime Giriş. Ankara: Alkan Yayıncılık.

Glickman, C. D. (1990). Supervision of Instruction. Boston: Allyn-Bacon.

Grace, G. (1995). School Leadership: Beyond Education Management. London: The Falmer Press.

Güler, B. A. (2000). Yerel Yönetimleri Güçlendirmek mi? Adem-i Merkeziyetçilik mi?. Çağdaş Yerel Yönetimler, 9(2), 14-29.

Gözübüyük, Ş. (2002). Yönetim Hukuku. Ankara: Turhan Kitapevi.

Günday, M. (2002). İdare Hukuku. Ankara: İmaj Yayıncılık.

Knezek, E. J. (2001). Supervision as a Selected Instructional Leadership Behavior of Elementary Principals and Student Achivement in Reading. Unpublished Doctoral Thesis. University of Texas, USA.

Langley, N., Jacobs, M. (2006). 5 Essential Skills for School Leaders. Maryland: Rowman\&Littlefield Education.

Liu, C. (1984). An Identification of Principals' Instructional Leadership Behaviors in Effective Schools. Unpublished Doctoral Thesis, University of Ciccinati, USA.

Luengo, J., Sevilla, D., Torres, M. (2005). From Centralization to Decentralization. European Education, 37(1), 46-61.

MacBeath J. (1998). Effective School Leadership: Responding to Change. London: Paul Chapman Publishing Ltd.

Marion, R. (2002). Leadership in Education. Ohio: Merrill Prentice Hall. 
MEB. (1999). 2000 Yılında Milli Eğitim. Ankara: Milli Eğitim Basımevi.

MEB. (2007). Lise ve Dengi Okullar Teftiş Rehberi. Ankara: Milli Eğitim Bakanlığı Teftiş Kurulu Başkanlığı Yayını.

Özdemir, M. (2008a). Kamusal Eğitimin Gelişimi: Eğitimde Devlet Sorumluluğu ve Eğitim Hakkı Kavramlarına Eleștirel Bir Bakıș. Yoğunluk, 19, 52-56.

Özdemir, M. (2008b). Eğitim Yönetiminde Yerelleşme Siyasaları. Amme Idaresi Dergisi, 41(3), 153-168.

Özdemir, M. (2008c). The Effects of New Public Management on Education. International Conference on Social Sciences. 21-24 August 2008, İzmir, Turkey.

Sezen, S. (1999). Devletçilikten Özelleştirmeye Türkiye'de Planlama. Ankara: TODAİE Yayınları.

Şimşek, H. (2002). Türkiye'de Eğitim Yöneticisi Yetiştirilemez. 21. Yüzyılın Eğitim Yöneticilerinin Yetiştirilmesi Sempozyumu. Ankara Üniversitesi 16-17 May1s 2002, Ankara.

Şişman, M., Taşdemir, İ. (2008). Türk Eğitim Sistemi ve Okul Yönetimi. Ankara: PegemA Yayıncilık.

Şişman, M., Turan, S. (2002). Dünyada Eğitim Yöneticilerinin Yetiştirilmesine İlişkin Başlıca Yönelimler ve Türkiye İçin Çıkarılabilecek Bazı Sonuçlar. 21. Yüzyılın Ĕ̈itim Yöneticilerinin Yetiştirilmesi Sempozyumu. Ankara Üniversitesi 16-17 Mayıs 2002, Ankara.

Tezcan, M. (1996). Eğitim Sosyolojisi. (10. Bask1). Ankara: Feryal Matbaası. Taymaz, H. (2003). Okul Yönetimi. Ankara: PegemA Yayıncılık.

Weber, M. (1996). Bureaucracy. In Shafritz, J. and Ott, J.S (Eds.) Classics of Organization Theory (p.81-86). New York: Harcourt Brace College Publishers. 